\title{
Tahap Preliminary Research Pengembangan LKPD Matematika Berbasis Kewirausahaan pada Materi SPLTV Kelas X SMA
}

\author{
Susilawati $^{1 *}$, Zulfah $^{2}$ \\ Universitas Pahlawan Tuanku Tambusai Bangkinang \\ ${ }^{*}$ susilawatisila98@gmail.com
}

\begin{abstract}
Abstrak
Tujuan penelitian ini adalah untuk menghasilkan produk berupa Lembar Kerja Peserta Didik (LKPD) berbasis kewirausahaan pada materi Sistem Persamaan Linier Tiga Variabel (SPLTV) dan mengetahui respon pendidik dan peserta didik terhadap LKPD berbasis kewirausahaan pada materi SPLTV. Penelitian ini menggunakan metodeResearch and Development (R\&D) berdasarkan model ADDIE yang dapat dilihat bahwa evaluasi bisa terjadi pada setiapempattahap yang bertujuan untuk kebutuhan revisi. Untuk tahap pertama yaitu tahap awal penelitian dilakukan analisis kebutuhan, analisis peserta didik, analisis kurikulum, analisis konsep, serta analisis bahan ajar yang ada.Berdasarkan hasil analisis pendahuluan, maka dapat diperoleh kesimpulan bahwa untuk dapat mengasah kemampuan penalaran matematis peserta didik, guru membutuhkan perangkat pembelajaran yang dapat membantu memfasilitasi peserta didik untuk berpikir secara logis dan sistematis dalam mengembangkan kemampuan penalaran matematis padamateri SPLTV.
\end{abstract}

Kata Kunci : Kewirausahaan, LKPD, SPLTV

\begin{abstract}
The purpose of this study was to produce a product in the form of an Entrepreneurship-Based Student Worksheet (LKPD) on the Material of the Three Variable Linear Equation System (SPLDV) and to find out the responses of educators and students to the entrepreneurshipbased LKPD on the SPLTV material. This study uses a Research and Development $(R \& D)$ method based on the ADDIE model which can be seen that evaluation can occur at any of the four stages aimed at revision needs. For the first phase, namely the initial stage of the study needs analysis, student analysis, curriculum analysis, concept analysis, and analysis of existing teaching materials. Based on the results of the preliminary analysis, it can be concluded that to be able to hone students' mathematical reasoning abilities, teachers need learning tools that can help facilitate students to think logically and systematically in developing mathematical reasoning abilities on SPLTV material.
\end{abstract}

Keywords: entrepreneurship, student work sheet, SPLTV

\section{Pendahuluan}

Salah satu kemampuan dasar yang penting untuk dicapai oleh siswa dalam pembelajaran matematika adalah kemampuan penalaran matematis(Aan Putra dkk, 2019).Penalaran menurut Ardhiyanti, Sutriyono, dan Fika (2019) adalah suatu proses berpikir dalam menarik kesimpulan yang berupa pengetahuan. Meicahyati (2018) menyebutkan bahwa materi matematika dan penalaran matematika merupakan dua hal yang tidak dapat dipisahkan, dimana materi matematika dipahami melalui penalaran, sedangkan penalaran dipahami dan dilatihkan melalui belajar materi matematika. Oleh karena itu, kemampuan penalaran matematis sangat penting dan 
dibutuhkan dalam mempelajari matematika. Kemampuan matematika yang mencakup kemampuan untuk berfikir secara logis dan sistematis merupakan ranah kognitif matematis paling tinggi. Penalaran matematik memiliki peran penting dalam proses berpikir seseorang.

Pembelajaran matematika di sekolah harus dapat menyiapkan siswa untuk memiliki kemampuan penalaran matematis sebagai bekal untuk menghadapi tantangan perkembangan dan perubahan. Kemampuan penalaran matematis diperlukan siswa baik dalam proses memahami matematika itu sendiri maupun dalam kehidupan sehari-hari (Mikrayanti, 2016). Terlebih dalam kehidupan nyata, kemampuan bernalar berguna pada saat menyelesaikan permasalahanpermasalah sehari-hari.Berdasarkan hasil wawancara dan observasi peserta didik, dapat disimpulkan bahwa peserta didik memiliki kemampuan penalaran yang rendah, peserta didik memiliki bakat dalam bidang kewirausahaan, bakat ini memungkinkan peserta didik untuk mengasah kemampuan penalaran matematis dalam memecahkan permasalahan di kehidupannya, dalam dan diluar sekolah.

Menyikapi rendahnya kemampuan penalaran matematis siswa, maka pendidik sebagai salah satu faktor keberhasilan dalam pembelajaran harus mengupayakan peningkatan kualitas pembelajaran. Diantaranya dengan menyediakan LKPD yang berkualitas dan bisa meningkatkan kemampuan penalaran matematis siswa.Penggunaan LKPD yang tepat dalam pembelajaran dapat meningkatkan pemahaman, minat dan motivasi peserta didik dalam belajar.LKPD juga dapat membantu peserta didik meningkatkan pemahaman, menyajikan data dengan menarik dan terpercaya, memudahkan penafsiran data dan memadatkan informasi (Arsyad, 2014).Hal ini sejalan dengan kurikulum 2013 yang sedang berlaku saat ini menganjurkan adanya aktivitas aktif siswa dalam proses pembelajaran (Permendikbud, 2013).

Matematika memiliki peran yang sangat penting dalam berbagai bidang, diantaranya adalah bidang kewirausahaan.Istilah wirausaha berasal dari bahasa Inggris yaitu entrepreneur. Pengertian wirausaha lebih lengkap dinyatakan oleh Joseph Schumpeter adalah entrepreneur as the person who destroys the existing economic order by introducing new products and services, by creating new forms of organization, or by exploiting new raw materials(Alma, 2010).Pembudayaan dan kewirausahaan sangat penting untuk diterapkan, dalam upaya tumbuhnya karakteristik jiwa unggul secara khusus jiwa entrepreuneur sangat ditentukan oleh pendidikan dibangku sekolah yang merupakan landasan yang kokoh kuat.Sebagai solusi untuk 
mengatasi pendidikan kewirausahaan dapat melalui pembelajaran matematika.Melalui hitunghitungan yang sederhana anak diajak untuk paham bagaimana matematika sangat berguna dan menyenangkan.

Lembar Kerja Peserta Didik (LKPD) merupakan sarana pembelajaran yang dapat digunakan pendidik dalam meningkatkan keterlibatan atau aktivitas peserta didik dalam proses belajar mengajar. Pada umumnya, LKPD berisi petunjuk praktikum, percobaan yang bisa dilakukan di rumah, materi untuk diskusi, dan soal- soal latihan maupun segala bentuk petunjuk yang mampu mengajak peserta didik beraktivitas dalam proses pembelajaran. LKPD sangat baik dipakai untuk meningkatkan keterlibatan peserta didik dalam proses pembelajaran. Penalaran matematika adalah salah satu proses berpikir yang dilakukan dengan cara menarik suatu kesimpulan (Nurahman, 2011).

Pada mata pelajaran Matematika, LKPD yang digunakan berupa lembaran-lembaran berbasis kewirausahaan. Pendidik perlu lebih mengembangkan LKPD khususnya pengaplikasian kedalam bidang kewirausahaan. Hal ini dikarenakan keterkaitan yang erat antara materi SPLTV dengan bidang kewirausahaan.

\section{Metode Penelitian}

Penelitian ini menggunakan metode penelitian dan pengembangan (research and development). Research and Development adalah metode penelitian yang digunakan untuk menghasilkan produk tertentu, dan menguji keefektifan produk tersebut (Sugiyono, 2011). Untuk dapat menghasilkan produk tertentu digunakan penelitian yang bersifat analisis kebutuhan dan untuk menguji keefektifan produk tersebut agar dapat berfungsi di masyarakat luas, maka diperlukan penelitian untuk menguji keefektifan produk tersebut. 


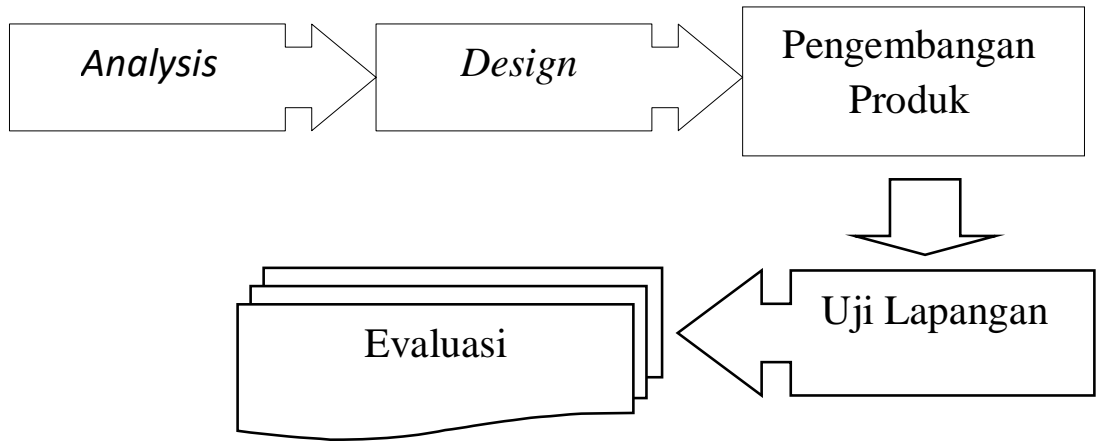

Sumber: (Made, 2014)

\section{Gambar 1. Langkah-langkah Penggunaan Metode Research and Development (R\&D)}

Benny (2009) salah satu model desain sistem pembelajaran yang memperlihatkan tahapan-tahapan dasar desain sistem pembelajaran yang sederhana dan mudah dipelajari adalah model ADDIE. Sesuai dengan namanya, terdiri daari lima fase atau tahap utama yaitu, $(A)$ nalysis, $(D)$ esign, $(D)$ evelopment, $(I)$ mplementation, dan $(E)$ valuation. Kelima fase atau tahap dalam model ADDIE, perlu dilakukan secara sistemik dan sistematik. Model ADDIE memiliki prosedur pada tiap-tiap tahapannya. Prosedur ini menjelaskan bagaimana membuat sebuah pengembangan. Adapun tahapannya sebagai berikut.

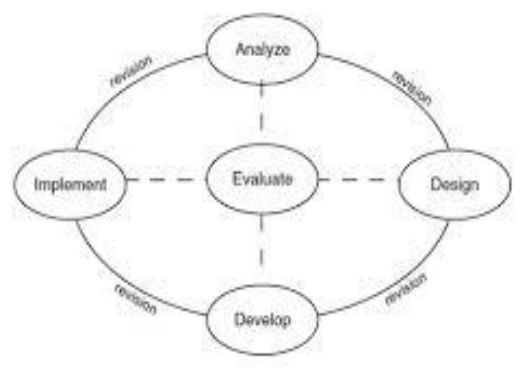

Sumber: (Heny, 2017)

\section{Gambar 2. Langkah-langkah Model ADDIE}

Dari bagan pengembangan ADDIE tersebut, dapat dilihat bahwa evaluasi bisa terjadi pada setiap empat tahap, dengan tujuan untuk kebutuhan revisi. Prosedur penelitian dan pengembangan memaparkan langkah-langkah prosedural yang ditempuh oleh peneliti dalam mengembangkan produk. Prosedur penelitian dan pengembangan ini secara tidak langsung akan 
memberi petunjuk bagaimana langkah prosedural yang dilalui mulai dari tahap awal sampai ke produk yang sudah bisa digunakan.

\section{Hasil Penelitian dan Pembahasan}

Analisis pendahuluan dilakukan peneliti pada peserta didik kelas X SMA. Hasil dari tahapan alisis terbagi menjadi hasil analisis kebutuhan, hasil analisis peserta didik, hasil analisis kurikulum, serta hasil analisis konsep.

\section{Hasil Analisis Kebutuhan}

Analisis kebutuhan terhadap produk yang akan dikembangkan melalui wawancara terhadap pendidik Matematika kelas X tahun ajaran 2019/2020 SMA/MA. LKPD yang digunakan seperti pada umumnya. Selain itu, perlu adanya pengembangan bahan ajar matematika berupa LKPD yang dapat membantu peserta didik dalam meningkatkan kemampuan peserta didik.

Dalam penelitian ini, peneliti memilih materi SPLTV untuk mengembangkan bahan ajar. Alasan peneliti memilih materi tersebut karena pada kegiatan transaksi jual beli seringkali menggunakan ilmu matematika terutama pada materi SPLTV, sehingga peneliti mampu mengembangkan soal-soal yang berkaitan dengan kegiatan transaksi kewirausahaan.

\section{Analisis Kurikulum}

Pada tahap ini dilakukan telaah terhadap kurikulum 2013 untuk mata pelajaran matematika kelas X SMA/MA.Analisis ini menjadi pedoman dalam melakukan pengembangan perangkat pembelajaran LKPD Berbasis KewirausahaanAnalisis untuk Kompetensi dasar materi ini adalah dikembangkannya indikator dengan menggunakan pembelajaran Kewirausahaan untuk mengorganisasikan materi dan menentukan tujuan pembelajaran yang ingin dicapai pada setiap pertemuan.Semua indikator yang dirancang telah disesuaikan dengan $\mathrm{KD}$ dan indikator pemecahan masalah namun tidak lepas dari masalah kehidupan sehari-hari.

Hasil penjabaran indikator pembelajaran untuk kompetensiinti pengetahuan pada materi Persamaan Linier Tiga Variabel yang diujicobakan dapat dilihat pada tabel. 


\section{Tabel 1. Kompetensi Dasar dan Indikator}

\begin{tabular}{|c|c|c|}
\hline Kompetensi Dasar & & Indikator pembelajaran \\
\hline $\begin{array}{l}\text { 3.2 } \\
\text { penyusun system } \\
\text { variable dari masalah } \\
\text { kontekstual }\end{array}$ & $\begin{array}{l}3.2 .1 \\
3.2 .2 \\
3.2 .3\end{array}$ & $\begin{array}{l}\text { Siswa dapat mengubah suatu masalah yang diketahui ke dalam } \\
\text { variabel } x, y \text {, dan } z \text {. } \\
\text { Siswa dapat menentukan masalah ke dalam bentuk tabel. } \\
\text { Siswa dapat menyusun sistem persamaan linear tiga variable } \\
\text { dari soal cerita. }\end{array}$ \\
\hline $\begin{array}{ll}4.1 & \text { Menyelesaikan } \\
\text { masalah kontekstual } \\
\text { yang berkaitan dengan } \\
\text { SPLTV }\end{array}$ & $\begin{array}{l}4.1 .2 \\
4.1 .3\end{array}$ & $\begin{array}{l}\text { Siswadapatmengidentifikasi sistem persamaan linear tiga } \\
\text { variabel menjadi persamaan linear dua variable dengan cara } \\
\text { mengeliminasi salah satu variabel } \\
\text { Siswa dapat mengidentifikasi system persamaan linear dua } \\
\text { variabel } \\
\text { Siswa dapat menyelesaikan ketiga variabel }\end{array}$ \\
\hline
\end{tabular}

Berdasarkan analisis isi kurikulum pada Tabel 1, susunan KD dengan indikator sudah sesuai. Karena sebelum melakukan penyelesaian terhadap suatu permaslahan, terlebih dahulu peserta didik diharapkan mampu memahami konsep terkait permasalahan yang diberikan dan peserta didik bisa menyelesaikan masalah kontekstual.

\section{Analisis peserta didik}

Berdasarkan hasil survei dan penyebaran angket di SMA/MA dan yang diisi oleh peserta didik, menunjukkan bahwa tidak ada menggunakan LKPD dalam proses pembelajaran Yang mengaitkan pada bidang kewirausahaan. Keterbatasan pendidik mata pelajaran Matematika dalam mengembangkan bahan ajar LKPD. Dalam suatu pembelajaran matematika, pendidik perlu memberikan motivasi kepada peserta didik agar mereka mau dan mampu menyelesaikan soalsoal, dan bila perlu membimbingnya sampai mereka dapat menyelesaikannya. Bimbingan yang dimaksud dapat diberikan secara lisan ataupun secara tertulis, namun bantuan secara tertulis dalam lembar kerja peserta didik jauh lebih efektif, karena dapat dibaca secara berulang-ulang oleh peserta didik. Lembar Kerja Peserta Didik merupakan salah satu alternatif pembelajaran yang tepat bagi peserta didik.

Oleh karena itu peneliti memberikan angket kepada kelas X IPS yaitu 20 peserta didik terkait pelajaran matematika. Diperoleh data dari beberapa pertanyaan yang diajukan. Dari hasil angket terkait tanggapan bahan ajar yang digunakan peserta didik dalam pelajaran matematika. Melalui pertanyaan "Apakah bahan ajar yang kamu gunakan menarik?” dengan jawaban "tidak menarik", "biasa saja", "menarik" dan "sangat menarik" 32\% peserta didik yaitu 11 orang 
menjawab biasa saja, $46 \%$ peserta didik yaitu 16 orang menjawab tidak menarik, hanya $22 \%$ yaitu 7 orang yang menjawab menarik dan $0 \%$ yaitu tidak ada yang menjawab sangatmenarik.

Hasil kuesioner terkait tentang bahan ajar/modul seperti apa yang menarik bagi peserta didik dalam pelajaran matematika. Melalui pertanyaan "menurut kalian bahan ajar seperti apa yang menarik untuk digunakan?” dengan jawaban "LKPD bergambar”, "LKPD tidak berwarna”, "modul" dan "buku paket" 55\% peserta didik yaitu 12 orang menjawab LKPD berwarna, 0\% peserta didik yaitu tidak ada yang menjawab LKPD tidak bergambar, hanya 27\% yaitu 6 orang yang menjawab modul dan $18 \%$ yaitu 4 orang yang menjawab buku paket.

Hasil kuesioner terkait tentang LKPD seperti apa yang menarik bagi peserta didik dalam pelajaran matematika. Melalui pertanyaan "Apakah kalian tertarik jika LKPD bergambar dan berisi soal-soal berkaitan dengan kehidupan sehari-hari seperti pada bidang kewirausahaan? dengan jawaban "tidak tertarik", "biasa saja", "tertarik" dan "sangat tertarik" 9\% peserta didik yaitu 2 orang yang menjawab tidak tertarik, $18 \%$ peserta didik yaitu 4 orang yang menjawab biasa saja, 27\% yaitu 6 orang yang menjawab tertarik dan $46 \%$ yaitu 10 orang yang menjawab sangat tertarik.

Dari tanggapan peserta didik kelas X IPS terhadap kuesioner diatas dapat dilihat ketertarikan peserta didik terhadap Lembar Kerja Peserta Didik berbasis kewirausahaan pada materi Sistem Persamaan Linier Tiga Variabel.Selama ini, pada umumnya peserta didik hanya bermodal menghafal rumus untuk menyelesaikan soal-soal matematika. Hal tersebut dikarenakan matematika bersifat abstrak dan membutuhkan pemahaman konsep-konsep (Frensista, 2013).

Hal ini sejalan dengan kurikulum 2013 yang sedang berlaku saat ini menganjurkan adanya aktivitas aktif siswa dalam proses pembelajaran (Permendikbud, 2013). Dalam kurikulum 2013, proses pembelajaran menjadi kunci utama dalam implementasinya (Kusumangtyas, 2013).Implementasi kurikulum 2013 khususnya pada pembelajaran Matematika, siswa dituntut untuk dapat lebih aktif dalam menemukan hal-hal yang baru dan dapat menyelesaikan ataupun menyimpulkan setiap permasalahan yang diberikan.

\section{Analisis Konsep}

Analisis konsep bertujuan untuk menentukan isi dan materi pelajaran yang dibutuhkan dalam pengembangan LKPD yang akan dihasilkan, dengan cara mengidentifikasi konsep-konsep 
utama yang diajarkan, merinci dan menyusunnya secara sistematis sesuai dengan urutan penyajiannya. Materi sangat diperlukan untuk mencapai indikator pencapaian kompetensi. Setelah mengetahui materi yang dipelajari di kelas X SMA/MA, maka diperlukan analisis konsep. Peneliti mengambil materi transformasi geometri, hal ini didasarkan karena peserta didik cenderung kurang menyukai materi tersebut. Tidak adanya media pembelajaran yang secara khusus membantu merupakan salah satu alasan dari peserta didik yang kurang menyukai materi tersebut. Materi SPLTV memuat permasalahan yang mungkin banyak ditemui peserta didik dalam kehidupan sehari-hari dan peserta didik diharapkan mampu untuk menyelesaikan masalah tersebut.

\section{Simpulan}

Berdasarkan uraian hasil dan pembahasan diatas menunjukkan bahwa guru disekolah membutuhkan bahan ajar yang dapat mengasah kemampuan penalaran matematis peserta didik.Lembar Kerja Peserta Didik (LKPD) berbasis kewirausahaan sangat dibutuhkan untuk membantu peserta didik dalam mengembangkan kemampuan penalaran matematis. Selain itu, pembelajaran dengan menggunakan LKPD berbasis kewirausahaan mengajak peserta didik aktif mulai dari awal proses pembelajaran. Peserta didik juga diajarkan bagaimana cara berpikir logis dalam kehidupan sehari-hari.

\section{Referensi}

Alma, Buchari. (2010). Kewirausahaan untuk Umum dan Mahasiswa. Bandung: Alfabeta.

Ardhiyanti, E., Sutriyono, Fika, W.P. (2019). Deskripsi Kemampuan Penalaran Siswa Dalam Pemecahan Masalah Matematika Pada Materi Aritmatika Sosial. Jurnal Cendekia: Jurnal Pendidikan Matematika. (Vol.3,No.1)

Darhim M.H., Turmudi. (2019). Pengembangan Bahan Ajar Dan Lks Berbasis Generative MultiRepresentation Learning (Gmrl) Untuk Peningkatan Kemampuan Berpikir Aljabar. Jurnal cendekia: Jurnal Pendidikan Matematika (Vol.03 No.02).

Hendra, Aan Putra, Zulfah. (2019). Validitas Lembar Kerja Peserta Didik Berbasis Penemuan Terbimbing dalam Upaya Meningkatkan Pemahaman Konsep dan Kemampuan Penalaran Matematis" Edumatika Jurnal Riset Pendidikan Matematika (Vol.1,No.1).

Kemendikbud. (2014). Permendikbud No.58 Tahun 2014 tentang Tujuan Pembelajaran Matematika. Jakarta: Kementrian Pendidikan dan Kebudayaan RI. 
Mahendra, A.E. , Caswita, Baharata, H. (2019). "Pengembangan Lembar Kerja Peserta Didik Berbasis Problem Based Learning untuk Meningkatkan Kemampuan Penalaran Matematika" Desimal: Jurnal Matematika

Meicahyati. (2018). Meningkatkan Kemampuan Penalaran Matematik Siswa Smp Menggunakan Pendekatan Problem Possing Melalui Pembelajaran Kooperatif Tipe Jigsaw. Jurnal Cendekia: Jurnal Pendidikan Matematika. (Vol.2,No.2)

Risnawati, M. A. , Erdawati, N. (2019). Pengembangan Lembar Kerja Siswa Berbasis Group Investigationuntuk Memfasilitasi Kemampuan Penalaran Matematis Siswa SMP. Juring: Journal for Research in Mathematics Learning (Vol.1 ,No.3).

Sagala, S. (2013). Konsep dan Makna Pembelajaran. Bandung: Alfabeta.

Salirawati, D. (2011). Penyusunan dan Kegunaan LKS Dalam Proses Pembelajaran (Makalah FMIPA UNY Yogyakarta).

Sugyiono. (2011). Metode Penelitian Pendidikan Pendekatan Kuantitatif, Kualitatif, dan R\&D. Bandung: Alfabeta.

Surtini, S. (2014). Matematika Sebagai Salah Satu Pembelajaran untuk Menumbuhkan Jiwa Kewiraswastaan Mulai Dini. UPBJJ-UT Semarang, (Vol. 40, No.1)

Trianto. (2009). Mendesain Model Pembelajaran Inovatif dan Progresif. Jakarta: Kencana Prenada Media Group. 